KONSTAN
JURNAL FISIKA DAN PENDIDIKAN FISIKA
Volume 4, Nomor 2, Desember 2019
E-ISSN : 2460-9129 dan P-ISSN : 2460-9110
http://jurnalkonstan.ac.id/index.php/jurnal

\title{
VALIDITAS TES KETERAMPILAN BERPIKIR KREATIF MATERI TEKANAN ZAT DENGAN ANALISIS RASCH MODEL
}

\author{
Nurul Yuliadinda ${ }^{1)^{*}}$, Muslim $^{1}$, Ridwan Efendi ${ }^{1{ }^{1}}$ \\ ${ }^{1)}$ Program Studi Pendidikan Fisika, Fakultas Matematika dan Ilmu Pengetahuan Alam \\ Universitas Pendidikan Indonesia, Indonesia \\ Kampus UPI Bandung 40154
}

\section{Info Artikel \\ Sejarah Artikel: \\ Diterima Agustus 2019 \\ Disetujui Desember 2019 \\ Dipublikasikan Desember 2019}

Kata Kunci:

Analisis Rasch Model;

Keterampilan Berpikir

Kreatif; Validitas Tes

\begin{abstract}
Abstrak
Keterampilan berpikir kreatif (KBK) adalah salah satu keterampilan berpikir tingkat tinggi yang harus dimiliki oleh siswa dalam pembelajaran. Namun, untuk mengetahui keterampilan berpikir kreatif siswa diperlukan alat ukur berupa tes. Oleh karena itu, penelitian dilakukan dengan tujuan untuk mengetahui validasi isi dan validasi konstruk tes keterampilan berpikir kreatif dengan analisis Rasch model. Penelitian ini menggunakan metode kuantitatif deskriptif dengan menggunakan desain konstruksi dan validasi. Proses konstruksi menghasilkan enam butir soal tes keterampilan berpikir kreatif yang mengukur aspek fluency, flexibility dan originality dalam bentuk essay. Proses validasi didasarkan pada judgement lima ahli dan uji coba pada 190 sampel. Hasil validitas isi butir soal tersebut memiliki kategori tinggi dan sangat tinggi. Hasil analisis validitas konstruk dengan Rasch model menunjukan bahwa butir soal 1, 5, dan 6 adalah valid, dan butir soal 2, 3, dan 4 harus melalui tahap perbaikan redaksi soal terlebih dahulu sebelum digunakan kembali.
\end{abstract}

* Corresponding Author: nurulyuliadinda@gmail.com

\footnotetext{
Alamat korespodensi:

Universitas Pendidikan Indonesia, Indonesia Kampus UPI Bandung 40154

Email: nurulyuliadinda@gmail.com
} 


\section{PENDAHULUAN}

Keterampilan berpikir kreatif (KBK) adalah keterampilan berpikir tingkat tinggi yang dibutuhkan oleh siswa. Saavendra dan Opfer [1] menjelaskan bahwa pentingnya memiliki keterampilan berpikir kreatif untuk menghadapi abad 21 . Berpikir kreatif dan kreativitas dapat diartikan sebagai keterampilam untuk menghasilkan atau menciptakan sesuatu yang baru menurut Baron dan Munandar [2]. Kata baru dalam kreativitas ini bukan berarti hal yang benar-benar baru atau sesuatu yang belum pernah ada sebelumnya. Menghasilkan sesuatu yang baru dalam kreativitas berarti menciptakan sebuah hasil kombinasi yang sudah ada menjadi sesuatu yang baru, dan dapat menciptakan sebuah inovasi dari suatu hal yang sudah ada.

Untuk mengetahui keterampilan berpikir kreatif siswa, maka perlu dikembangkan tes yang dapat mengukur keterampilan berpikir kreatif siswa. Penulis melakukan wawancara tentang tes keterampilan berpikir kreatif dengan guru di salah satu sekolah menengah pertama di kota Tasikmalaya. Hasil wawancara tersebut menyatakan bahwa evaluasi atau tes yang sering digunakan adalah tes untuk mengukur pengetahuan kognitif siswa saja. Narasumber dari wawancara menyebutkan bahwa belum pernah memberikan tes keterampilan berpikir kreatif siswa selama beliau mengajar. Hasil wawancara tersebut membuktikan pentingnya mengkonstruksi tes keterampilan berpikir kreatif. Dari hasil wawancara tersebut, maka penelitian ini bertujuan untuk mengkonstruksi tes KBK dan mengetahui validasi isi dan validasi konstruk dari tes tersebut. Peneliti mengkaji beberapa jurnal mengenai tes keterampilan berpikir kreatif diantaranya Urban [3], Cheung dan Lau [4], Hu dan Adey [5], Alrubai [6] dan Pekmez, et al. [7]. Dari hasil kajian tersebut, peneliti memilih mengkonstruksi tes dengan mengadaptasi bentuk tes yang digunakan Hu dan Adey [5] dan menggunakan bentuk soal yang diadaptasi dari Alrubai [6].

Bentuk tes yang digunakan adalah Torrance Test of Creative Thinking dengan pendekatan scientific creativity. Bentuk soal yang digunakan diantaranya; Memberikan pertanyaan : mengajukan pertanyaan yang mungkin ditanyakan sesuai gambar ; menerka penyebab: menuliskan alasan yang mengarah pada sebuah situasi atau kejadian ; menerka penyebab dari sebuah kejadian: menuliskan alasan yang menyebabkan atau hasil dari sebuah kejadian; memperbaharui atau memperbaiki sebuah produk: menuliskan seluruh kemungkinan perubahan atau tambahan yang dapat diperbaharui pada produk; penggunaan alternatif lain dari produk umum: menuliskan sebanyak mungkin kemungkinan penggunaan saintifik pada suatu produk; dan menduga: menuliskan hasil dugaan dan asumsi pada sebuah kejadian yang dapat terjadi.

\section{METODE PENELITIAN}

Pada penelitian ini digunakan metode kuantitatif deskriptif dengan menggunakan desain konstruksi dan validasi. Desain yang digunakan dalam penelitian ini diadaptasi oleh Crocker dan Algina [8]. Desain ini secara umum melakukan langkah kerja mengkonstruksi soal dan memvalidasi instrument tes. Desain penelitian konstruksi dan validasi secara khusus diadaptasi dari Crocker dan Algina yaitu; mengidentifikasi tujuan dan kegunaan dari instrumen tes; mengidentifikasi karakter dari tes yang akan dikonstruksi; menyusun spesifikasi instrument tes; mengkonstrusi butir soal atau item; review soal oleh ahli; melakukan 
uji coba terbatas; melakukan uji coba luas; melihat validitas tes; analisis hasil; dan penarikan kesimpulan.

Partisipan yang terlibat dalam penelitian ini adalah siswa sekolah menengah pertama (SMP) dari 2 sekolah yang telah mendapatkan pembelajaran tentang materi tekanan zat. Pemilihan SMP untuk uji coba luas adalah SMP negeri dan SMP swasta. Penarikan sampel dalam penelitian ini menggunakan teknik purposive sampling. Penelitian dilaksanakan dengan sampel sebanyak 190, namun penelitian ini menggunakan 150 data sampel yang mengisi instrumen tes paling lengkap. Data yang didapatkan dari review ahli akan dianalisis menggunakan analisis V Aiken untuk mengetahui validitas isi tes. Sedangkan data uji coba akan dianalisis menggunakan Rasch model dengan berbantuan aplikasi Ministep untuk mengetahui validitas konstruk tes. Peneliti memilih Rasch model dikarenakan pendekatan ini menghasilkan suatu skala pengukuran dengan interval yang sama nantinya bisa memberikan informasi secara akurat tentang peserta tes maupun kualitas soal yang dikerjakan [9].

\section{HASIL DAN PEMBAHASAN}

Dari hasil identifikasi kegunaan tes dengan cara studi literatur terhadap berbagai sumber yaitu buku, jurnal, maupun artikel yang berkaitan dengan penelitian yang dilakukan. Peneliti memilih mengkonstruksi tes keterampilan berpikir kreatif dengan materi tekanan zat. Hasil Identifikasi karakteristik tes dari berbagai jurnal, peneliti menggunakan bentuk tes uraian atau essay dengan bentuk tes yang digunakan adalah Torrance Test of Creative Thinking dengan pendekatan scientific creativity, dan bentuk soal yang diadaptasi dari Alrubai [6]. Tahap spesifikasi tes menghasilkan sebuah kisi-kisi tes keterampilan berpikir kreatif yang terdiri dari 12 soal. Setelah spesifikasi tes siap, peneliti melakukan tahap berikutnya yaitu konstruksi butir soal. Dari kisi-kisi yang sudah disusun, peneliti membuat indikator soal yang sesuai dengan bentuk soal KBK pada materi tekanan zat. Indikator soal yang telah dibuat dikembangkan menjadi sebuah butir soal beserta dengan alternatif jawabannya.

Proses pertama yang dilakukan dalam tahap validasi adalah review butir soal yang telah dikonstruksi. Terdapat enam aspek penilaian dari setiap butir soal diantaranya; 1) kesesuaian butir soal dengan kompetensi yang ingin dicapai; 2) kesesuaian indikator keterampilan berpikir kreatif dengan butir soal; 3) kesesuaian kalimat tanya dan perintah menuntut jawaban yang dikehendaki; 4) pedoman penskoran; 5) kejelasan dari kalimat; dan 6) mengenai tata bahasa yang digunakan. Hasil review dan penilaian dosen ini kemudian dianalisis menggunakan V Aiken. Dari hasil validitas ahli, peneliti melihat nilai validitasnya dan mengambil keputusan untuk pengambilan soal dengan nilai validitas yang paling tinggi dari butir dengan bentuk soal yang sama. Rata-rata nilai validitas setiap butir soal, peneliti memilih butir soal nomor $1,4,5,8,9$, dan 11. Berdasarkan pembagian karegori menurut Pratiwi [10], setiap butir soal memiliki kategori validasi seperti yang disajikan dalam Tabel 1. Hasil validitas ahli ini disertai dengan beberapa revisi pada setiap butir soal. 
Tabel 1. Kategori Validitas Isi dari Setiap Butir Soal

\begin{tabular}{ccc}
\hline $\begin{array}{c}\text { Butir } \\
\text { Soal ke- }\end{array}$ & Nilai Validasi & Kategori \\
\hline 1 & 0,76 & Tinggi \\
4 & 0,78 & Tinggi \\
5 & 0,80 & Tinggi \\
8 & 0,80 & Tinggi \\
9 & 0,84 & Sangat Tinggi \\
11 & 0,80 & Tinggi \\
\hline
\end{tabular}

Uji coba terbatas dilakukan pada 17 siswa menggunakan tes keterampilan berpikir kreatif. Uji coba terbatas ini bertujuan untuk mengetahui alokasi waktu pengerjaan tes yang telah dikosnturksi. Setelah mengerjakan tes, peneliti memilih enam orang siswa sebagai partisipan secara acak dan melakukan wawancara kognitif mengenai tes keterampilan berpikir kreatif yang telah dikerjakan. Hasil wawancara menyatakan bahwa siswa harus menghabiskan waktu yang sedikit lama untuk memahami soal yang mereka kerjakan. Hal ini dikarenakan mereka tidak mengenali soal yang mereka kerjakan. Siswa yang diwawancara berpendapat bahwa mereka lebih mengenal soal hitungan dibandingkan soal yang dikonstruksi oleh peneliti. Hasil uji coba terbatas ini pun menghasilkan beberapa revisi mengenai redaksi soal.

Setelah pengambilan data dalam uji coba luas, dilakukan analisis dengan Rasch model untuk mengetahui validasi konstruk tes KBK. Dalam analisis ini, dilakukan pembagian data menjadi dua kelompok yaitu 75 data pertama di bagian 1 . Dan 75 data kedua di bagian 2. Dalam kasus ini maka dilakukan uji homogenitas. Uji homogenitas bertujuan untuk mengetahui kelompok data memiliki varians yang sama atau tidak. Untuk mengetahui bagaimana homogenitas dari dua kelompok tersebut, maka terlebih dahulu dilakukan uji homogenitas menggunakan SPSS. Hasil uji homogenitas disajikan pada Tabel 2.

Tabel 2. Hasil Uji Homogenitas Menggunakan SPSS

\begin{tabular}{cc}
\hline Butir Soal ke- & Nilai Signifikansi (Sig.) \\
\hline 1 & 0,764 \\
2 & 0,853 \\
3 & 0,505 \\
4 & 0,958 \\
5 & 0,767 \\
6 & 0,886 \\
\hline
\end{tabular}


Pengambilan keputusan dilihat dari nilai signifikansi hasil uji homogenitas. Jika nilai signifikansi lebih dari 0,05 , maka kelompok data memiliki varians yang homogen. Tabel 2 menunjukan bahwa nilai signifikansi >0,05. Nilai tersebut menunjukan dua kelompok data memiliki varians yang homogen pada setiap butir soal tes. Validitas butir soal tes dilakukan dengan menganalisis data menjadi dua kelompok yaitu 75 data pertama dan 75 data kedua. 75 data pertama pada Tabel 3 dan 75 data kedua pada Tabel 4 Adapun hasil analisis validitas adalah sebagai berikut.

Tabel 3. Hasil Validasi Butir Soal dari Data 1-75

\begin{tabular}{cccc}
\hline $\begin{array}{c}\text { Butir } \\
\text { Soal ke- }\end{array}$ & $\begin{array}{c}\text { Outfit } \\
\text { MNSQ }\end{array}$ & $\begin{array}{c}\text { Outfit } \\
\text { ZSTD }\end{array}$ & $\begin{array}{c}\text { Pt-Measure } \\
\text { Corr. }\end{array}$ \\
\hline 1 & 1,05 & 0,31 & 0,80 \\
2 & 0,80 & $-0,24$ & 0,82 \\
3 & 0,82 & $-1,08$ & 0,85 \\
4 & 0,66 & $-0,91$ & 0,87 \\
5 & 0,77 & $-0,27$ & 0,72 \\
6 & 1,05 & 0,29 & 0,80 \\
\hline
\end{tabular}

Tabel 4. Hasil Validasi Butir Soal dari Data 76-150

\begin{tabular}{cccc}
\hline $\begin{array}{c}\text { Butir Soal } \\
\text { ke- }\end{array}$ & $\begin{array}{c}\text { Outfit } \\
\text { MNSQ }\end{array}$ & $\begin{array}{c}\text { Outfit } \\
\text { ZSTD }\end{array}$ & $\begin{array}{c}\text { Pt-Measure } \\
\text { Corr. }\end{array}$ \\
\hline 1 & 1,27 & 1,38 & 0,76 \\
2 & 0,69 & $-0,84$ & 0,86 \\
3 & 0,91 & $-0,55$ & 0,85 \\
4 & 0,58 & $-1,73$ & 0,88 \\
5 & 1,01 & 0,21 & 0,70 \\
6 & 1,02 & 0,19 & 0,79 \\
\hline
\end{tabular}

Validasi butir soal dilihat dari 3 kategori yaitu dari nilai outfit means square, outfit z-standard, dan point measure correlation dengan rentang nilai yang sudah ditentukan. Tabel 3 dan tabel 4 , tertera tiga kategori yang dapat menentukan validitas dari setiap butir soal tes. Butir soal nomor 1, 5, dan 6 memenuhi kriteria dari tiga kategori. Data pada tabel 3 dan tabel 4 menunjukan bahwa butir soal tersebut baik untuk dijadikan sebagai alat pengukuran. Hal tersebut dapat dilihat dari nilai outfit mnsq yang masuk pada rentang yang sudah ditentukan. Nilai outfit mnsq yang masih masuk dalam rentangnya ini menunjukan bahwa penyimpangan data masih dapat ditoleransi.

Butir soal nomor 1, 5, dan 6 adalah data mempunyai perkiraan logis dan sesuai dengan model ideal (persebaran data yang terdistribusi secara normal). Persebaran data tersebut dapat dilihat digrafik expected score icc pada gambar 1 sampai gambar 6. Gambar 1 sampai gambar 6 menunjukan bahwa persebaran data masih berada disekitar kurva ruang kepercayaan outfit dan kurva ruang kepercayaan 
infit. Hal tersebut juga didasarkan pada nilai outfit zstd yang berada pada rentang yang sudah ditentukan. Butir soal nomor 1, 5, dan 6 pun memiliki korelasi yang baik satu sama lain. Hal tersebut didasarkan pada nilai pt-measure corr yang bernilai positif dan berada pada rentang yang sudah ditentukan. Nilai pt-measure corr yang positif menunjukan bahwa antara butir soal tersebut berkorelasi, dan nilainya berada pada rentang yang sudah ditentukan menunjukan bahwa butir soal nomor 1, 5, dan 6 memiliki korelasi yang baik.

Butir soal nomor 2 menunjukan hasil analisis yang sedikit berbeda. Pada tabel 3, hasil analisis menunjukan bahwa bahwa butir soal nomor 2 baik untuk dijadikan sebagai alat pengukuran dan data mempunyai perkiraan logis dan sesuai dengan model ideal (persebaran data yang terdistribusi secara normal). Persebaran data tersebut dapat dilihat digrafik Expected Score ICC pada Gambar 7 dan Gambar 8. Gambar 7 dan Gambar 8 menunjukan bahwa persebaran data masih berada disekitar kurva ruang kepercayaan Outfit dan kurva ruang kepercayaan Infit. Nilai PtMeasure Corr yang positif menunjukan bahwa antara butir soal tersebut berkorelasi, dan nilainya berada pada rentang yang sudah ditentukan menunjukan bahwa butir soal nomor 1, 2, 5, dan 6 memiliki korelasi yang baik. Sedangkan pada Tabel 4, butir soal nomor 2 tidak memenuhi kriteria pada satu kategori. Kategori yang tidak memenuhi kriteria adalah nilai Pt-Measure Corr. Dari data tersebut, nilai Pt-Measure Corr memiliki nilai positif yang menunjukan bahwa butir soal nomor 2 pun berkorelasi dengan butir soal lainnya. Namun nilai Pt-Measure Corr butir soal nomor 2 tidak berada pada kriteria yang sudah ditentukan.

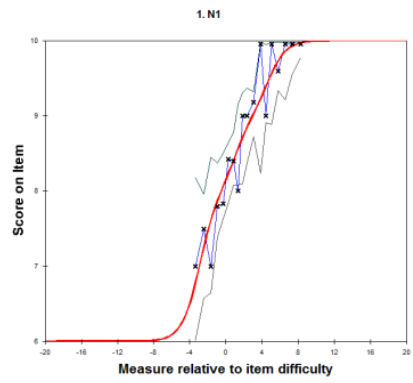

Gambar 1. Grafik Expected Score ICC Butir Soal Nomor 1 untuk Data 1-75

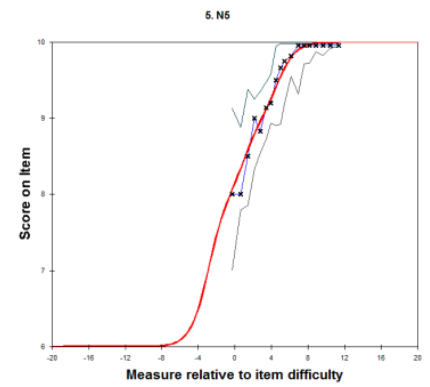

Gambar 3. Grafik Expected Score ICC Butir Soal Nomor 5 untuk Data 1-75

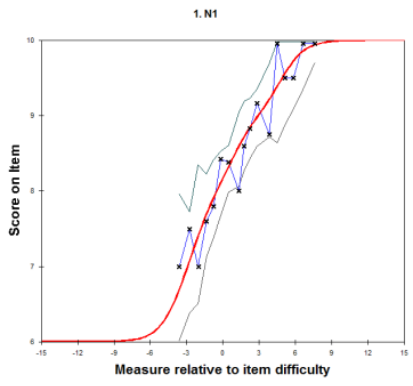

Gambar 2. Grafik Expected Score ICC Butir Soal Nomor 1 untuk Data 76-150

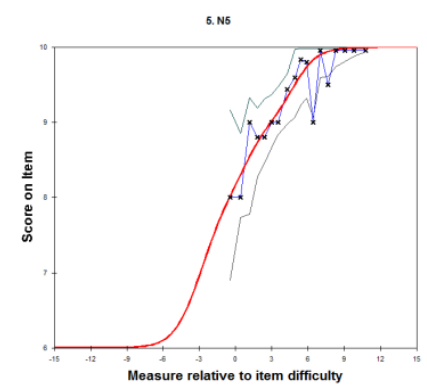

Gambar 4. Grafik Expected Score ICC Butir Soal Nomor 5 untuk Data 76-150 


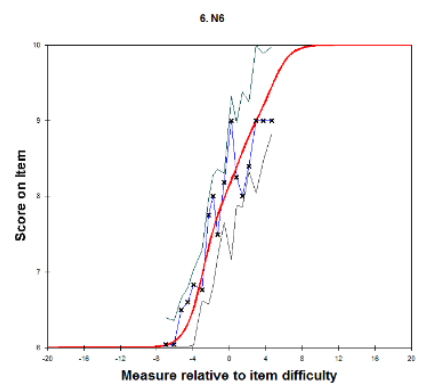

Gambar 5. Grafik Expected Score ICC Butir Soal Nomor 6 untuk Data 1-75

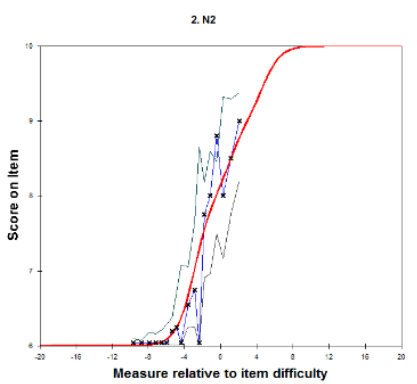

Gambar 7. Grafik Expected Score ICC Butir Soal 2 untuk Data 1-75

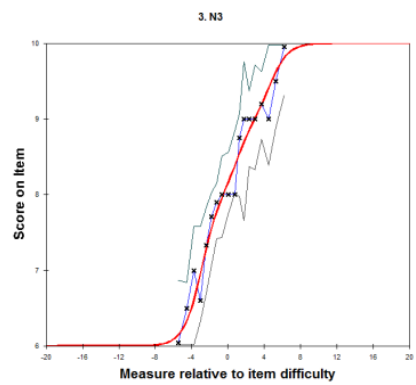

Gambar 9. Grafik Expected Score ICC Butir Soal 3 untuk Data 1-75

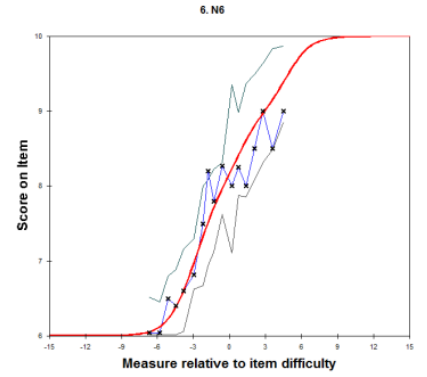

Gambar 6. Grafik Expected Score ICC Butir Soal Nomor 6 untuk Data 76-150

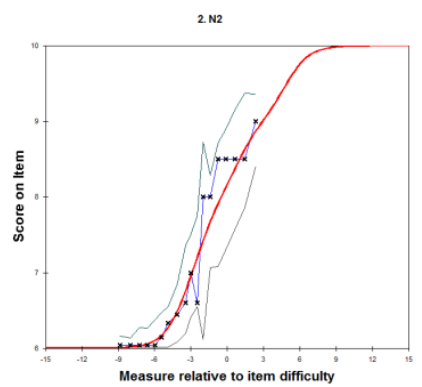

Gambar 8. Grafik Expected Score ICC Butir Soal 2 untuk Data 76-150

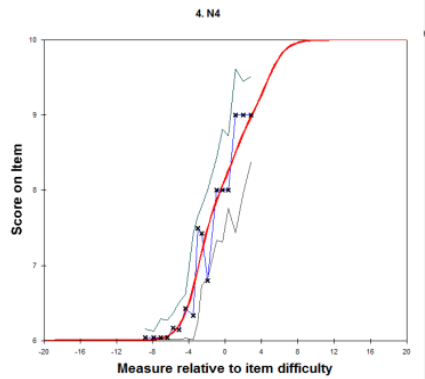

Gambar 10. Grafik Expected Score ICC Butir Soal 4 untuk Data 1-75 


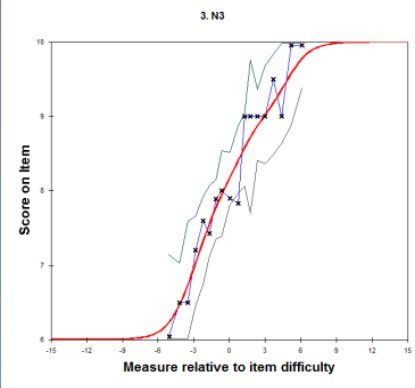

Gambar 11. Grafik Expected Score ICC Butir Soal 3 untuk Data 76-150

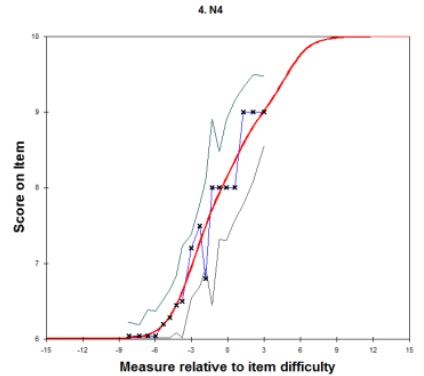

Gambar 12. Grafik Expected Score ICC Butir Soal 4 untuk Data 76-150

Berbeda dengan butir soal nomor 1, 2, 5, dan 6, butir soal nomer 3 dan 4 hanya memenuhi kriteria dari dua kategori saja. Data pada Tabel 3 dan Tabel 4 menunjukan bahwa butir soal tersebut baik untuk dijadikan sebagai alat pengukuran. Data yang didapatkan pun mempunyai perkiraan logis dan sesuai dengan model ideal (persebaran data yang terdistribusi secara normal). Persebaran data tersebut dapat dilihat pada Gambar 9 sampai Gambar 12. Gambar 9 sampai Gambar 12 menunjukan bahwa persebaran data masih berada disekitar kurva ruang kepercayaan Outfit dan kurva ruang kepercayaan Infit. Kategori yang tidak memenuhi kriteria adalah nilai Pt-Measure Corr. Dari data tersebut, nilai Pt-Measure Corr memiliki nilai positif yang menunjukan bahwa butir soal nomor 3 dan 4 pun berkorelasi dengan butir soal nomor 1, 2, 5, dan 6. Namun nilai Pt-Measure Corr butir soal nomor 3 dan 4 tidak berada pada kriteria yang sudah ditentukan. Wibisono menyatakan bahwa jika butir soal tidak memasuki kriteria hanya pada 1 kategori saja, butir soal tidak perlu dieleminasi, tetapi butir soal hanya disarankan untuk dilakukan perubahan redaksional. Dari pernyataan tersebut, maka butir soal 2, 3, dan 4 tidak perlu dieleminasi, melainkan dilakukan perubahan redaksional.

\section{SIMPULAN DAN SARAN}

Tes keterampilan berpikir kreatif materi tekanan zat mengkonstruksi 12 butir soal (item) dengan bentuk soal uraian. Tes ini mengukur aspek keterampilan berpikir kreatif diantaranya fluency, flexibility, dan originality. Dari hasil penelitian yang telah dilakukan, maka dapat diketahui bagaimana validitas dari butir soal yang dikonstruksi. Berdasarkan hasil validitas isi tes keterampilan berpikir kreatif dari penilaian validator berdasarkan analisis $\mathrm{V}$ Aiken, maka butir soal direduksi menjadi 6 butir soal. Hasil analisis V Aiken ini menunjukan bahwa validasi isi pada 6 butir soal yang dikonstruksi adalah tinggi dan sangat tinggi.

Hasil analisis validitas konstruk menunjukan bahwa terdapat tiga soal yang valid (butir soal nomor 1, 5, dan 6) dan 3 soal yang harus diperbaiki kembali (butir soal nomor 2, 3, dan 4). Butir soal yang masih harus diperbaiki tersebut dikarenakan data yang didapatkan tidak menunjukan korelasi yang baik. Maka dari itu butir soal nomor 2, 3, dan 4 dapat digunakan kembali jika sudah melalui tahap perbaikan redaksi soal. Tes keterampilan berpikir kreatif materi tekanan zat dapat digunakan oleh praktisi pendidikan sebagai alat evaluasi yang bertujuan untuk mengukur keterampilan berpikir kreatif siswa. Dalam tahap konstruksi soal, peneliti selanjutnya 
disarankan untuk lebih memperhatikan redaksi soal agar tes dapat digunakan untuk mengukur kemampuan berpikir kreatif dengan baik.

\section{UCAPAN TERIMA KASIH}

Penulis mengucapkan terimakasih kepada Bapak Dr. Muslim, M.Pd. serta Bapak Ridwan Efendi, M.Pd. yang telah membimbing penulis selama melaksanakan penelitian hingga terselesaikan artikel ini.

\section{DAFTAR PUSTAKA}

[1] Saavedra, A. R., dan Opfer, V. D. (2012). Learning 21st-century skills requires 21st-century teaching. Phi Delta Kappan, 8-13.

[2] Munandar, U. (2002). Kreativitas dan Keterbakatan. Strategi Mewujudkan Potensi Kreatif dan Bakat. Jakarta: PT. Gramedia Pustaka Utama.

[3] Urban, K. K. (2005). Assessing Creativity: The Test for Creative ThinkingDrawing Production (TCT-DP). International Education Journal, 272-280.

[4] Cheung, P. C., \& Lau, S. (2010). Gender Differences in The Creativity of Hong Kong School Children: Comparison by Using The New Electronic Wallach-Kogan Creativity Tests. Creativity Research Journal, 194-199.

[5] Hu, W., \& Adey, P. (2002). A Scientific Creativity Test for Secondary School Students. International Journal of Science Education, 389-403.

[6] Alrubai, Farah M. R. H. (2014). The Effectiveness of the Brainstroming Technique Toward Enhacing Creative and Cricital Thinking Skills among Secondary Iraqi Physics Students. Thesis: University of Malaya Kuala Lumpur.

[7] Pekmez, E. S., Aktamıs, H., \& Taskın, B. C. (2009). Exploring Scientific Creativity of 7 Th Grade Students. Journal of Qafqaz University, 1409-1415.

[8] Crocker, Linda. M., dan Algina, J. (1986). Introduction To Classical and Modern Test Theory. New york: Holt, Rinehart and Winston

[9] Wibisono, S. (2019). Aplikasi Model Rasch untuk Validasi Instrumen Pengukuran Fundamentalisme Agama Bagi Responden Muslim. Jurnal Pengukuran Psikologi dan Pendidikan Indonesia (JP3I), 3(3).

[10] Pratiwi, P. A. (2014). Penerapan Levels of Inquiry untuk Meningkatkan Achievements Siswa SMP pada Pokok Bahasan Optik: http://respository.upi.edu/11441/6/S_FIS_1000294_Chapter3.pdf 